\title{
Large-Scale Tissue Microarray Evaluation Corroborates High Specificity of High-Level Arginase-1 Immunostaining for Hepatocellular Carcinoma
}

\author{
Maximilian Lennartz ${ }^{1} \oplus$, Eva Gehrig ${ }^{1}$, Sören Weidemann ${ }^{1}$, Natalia Gorbokon ${ }^{1}$, Anne Menz ${ }^{1}$, \\ Franziska Büscheck ${ }^{1}$, Claudia Hube-Magg ${ }^{1}$, Andrea Hinsch ${ }^{1}$, Viktor Reiswich ${ }^{1}$, Doris Höflmayer ${ }^{1}$, \\ Christoph Fraune ${ }^{1}$, Frank Jacobsen ${ }^{1}$, Christian Bernreuther ${ }^{1}$, Patrick Lebok ${ }^{1}$, Guido Sauter ${ }^{1}$, \\ Waldemar Wilczak ${ }^{1}$, Stefan Steurer ${ }^{1}$, Eike Burandt ${ }^{1}$, Andreas H. Marx ${ }^{1,2}$, Ronald Simon ${ }^{1, * \mathbb{D}}$, Till Krech ${ }^{1,3}$, \\ Till S. Clauditz ${ }^{1}$, Sarah Minner ${ }^{1}$, David Dum ${ }^{1}$ and Ria Uhlig ${ }^{1}$
}

check for updates

Citation: Lennartz, M.; Gehrig, E.; Weidemann, S.; Gorbokon, N.; Menz, A.; Büscheck, F.; Hube-Magg, C.; Hinsch, A.; Reiswich, V.; Höflmayer, D.; et al. Large-Scale Tissue Microarray Evaluation Corroborates High Specificity of High-Level Arginase-1 Immunostaining for Hepatocellular Carcinoma. Diagnostics 2021, 11, 2351. https://doi.org/10.3390/ diagnostics11122351

Academic Editor: Roxana Sirli

Received: 1 November 2021 Accepted: 9 December 2021 Published: 14 December 2021

Publisher's Note: MDPI stays neutral with regard to jurisdictional claims in published maps and institutional affiliations.

Copyright: (c) 2021 by the authors. Licensee MDPI, Basel, Switzerland. This article is an open access article distributed under the terms and conditions of the Creative Commons Attribution (CC BY) license (https:/ / creativecommons.org/licenses/by/ $4.0 /)$.
1 Institute of Pathology, University Medical Center Hamburg-Eppendorf, 20246 Hamburg, Germany; m.lennartz@uke.de (M.L.); eva.gehrig@hotmail.de (E.G.); s.weidemann@uke.de (S.W.); n.gorbokon@uke.de (N.G.); a.menz@uke.de (A.M.); f.buescheck@uke.de (F.B.); c.hube@uke.de (C.H.-M.); a.hinsch@uke.de (A.H.); v.reiswich@uke.de (V.R.); d.hoeflmayer@uke.de (D.H.); c.fraune@uke.de (C.F.); f.jacobsen@uke.de (F.J.); c.bernreuther@uke.de (C.B.); p.lebok@uke.de (P.L.); g.sauter@uke.de (G.S.); w.wilczak@uke.de (W.W.); s.steurer@uke.de (S.S.); e.burandt@uke.de (E.B.); andreas.marx@klinikum-fuerth.de (A.H.M.); t.krech@uke.de (T.K.); t.clauditz@uke.de (T.S.C.); s.minner@uke.de (S.M.); d.dum@uke.de (D.D.); r.uhlig@uke.de (R.U.)

2 Department of Pathology, Academic Hospital Fuerth, 90766 Fuerth, Germany

3 Institute of Pathology, Clinical Center Osnabrueck, 49076 Osnabrueck, Germany

* Correspondence: r.simon@uke.de; Tel.: +49-40-74105-7214

Abstract: Arginase- 1 catalyzes the conversion of arginine to ornithine and urea. Because of its predominant expression in hepatocytes, it serves as a marker for hepatocellular carcinoma, although other tumor entities can also express arginase-1. To comprehensively determine arginase-1 expression in normal and neoplastic tissues, tissue microarrays containing 14,912 samples from 117 different tumor types and 608 samples of 76 different normal tissue types were analyzed by immunohistochemistry. In normal tissues, arginase-1 was expressed in the liver, the granular layer of the epidermis, and in granulocytes. Among tumors, a nuclear and cytoplasmic arginase- 1 immunostaining was predominantly observed in hepatocellular carcinoma, where $96 \%$ of 49 cancers were at least moderately positive. Although 22 additional tumor categories showed occasional arginase immunostaining, strong staining was exceedingly rare in these entities. Staining of a few tumor cells was observed in squamous cell carcinomas of various sites. Staining typically involved maturing cells with the beginning of keratinization in these tumors and was significantly associated with a low grade in 635 squamous cell carcinomas of various sites $(p=0.003)$. Teratoma, urothelial carcinoma and pleomorphic adenomas sometimes also showed arginase expression in areas with squamous differentiation. In summary, arginase-1 immunohistochemistry is highly sensitive and specific for hepatocellular carcinoma if weak and focal staining is disregarded.

Keywords: arginase-1; immunohistochemistry; tissue micro array; neoplastic tissue; hepatocellular carcinoma

\section{Introduction}

Arginase- 1 is encoded by the ARG1 gene located at 6q23. It acts as a cytosolic manganese-dependent enzyme that catalyzes the conversion of arginine to ornithine and urea in the final step of the urea cycle [1-4]. Among normal tissues, it is predominantly expressed in hepatocytes and inflammatory cells. Because arginase- 1 expression is usually retained in hepatocellular carcinoma, a cancer derived from hepatocytes, the immunohistochemical detection of arginase expression is commonly used to support the difficult 
distinction of hepatocellular carcinoma from cholangiocellular carcinoma and metastases to the liver [5]. This procedure is supported by more than 20 studies demonstrating arginase- 1 expression in $80-100 \%$ of hepatocellular carcinomas [6-26].

Multiple studies have suggested that arginase-1 expression of tumor cells is largely absent in other important tumor types, such as renal cell carcinomas [8,25], ductal adenocarcinoma of the pancreas [8,21], gastric adenocarcinoma [25], esophageal adenocarcinoma [25], adenocarcinoma of the lung [25], and in lobular breast cancer [25]. The extent to which arginase-1 expression is specific for hepatocellular carcinoma is still unclear, however. Studies have demonstrated arginase-1 expression in $0-7 \%$ of prostate cancer [25-27], 6\% of adenocarcinomas of the ampulla Vateri [28], 84\% of squamous cell carcinoma of the oral cavity and the larynx [14], and "high" expression in $47 \%$ of the 79 analyzed invasive breast carcinomas of no special type (NST) [29]. In one study, multiple soft tissue tumors were described to show arginase-1 expression in up to $100 \%$ of cases [30]. The published arginase-1 positivity rates are also markedly variable in tumor entities that are often seen in the liver such as cholangiocarcinoma (positivity described in $0-68 \%$ of cases, $[8,19,24-26,31]$, breast cancer NST (0-47\%), [8,18,26,29]), colorectal adenocarcinoma (0-100\%) [8,26,32,33] and even hepatocellular carcinoma $45-100 \%,[6,8,9,11,12,22,26]$. This data variability is most likely due to the use of different antibodies, staining protocols and criteria for staining interpretation in the respective studies.

To better understand the prevalence and diagnostic utility of arginase- 1 expression in cancer, a comprehensive study analyzing large numbers of neoplastic and non-neoplastic tissues under highly standardized conditions is desirable. For this purpose, arginase-1 expression was analyzed in more than 14,000 tumor tissue samples from 117 different tumor types and subtypes as well as 76 non-neoplastic tissue categories by immunohistochemistry (IHC) in a tissue microarray (TMA) format in this study.

\section{Materials and Methods}

Tissue Microarrays (TMAs). Our normal tissue TMA was composed of 8 samples from 8 different donors for each of the 76 different normal tissue types (608 samples on one slide). The cancer TMAs contained a total of 14,912 primary tumors from 117 tumor types and subtypes. The composition of normal and tumor TMAs is described in the results section. All samples were obtained from the archives of the Institutes of Pathology, University Hospital of Hamburg, Germany, the Institute of Pathology, Clinical Center Osnabrueck, Germany, and Department of Pathology, Academic Hospital Fuerth, Germany. Tissues were fixed in $4 \%$ buffered formalin and then embedded in paraffin. The TMA manufacturing process was described earlier in detail [34-36]. In brief, one tissue spot (diameter: $0.6 \mathrm{~mm}$ ) was transferred from a cancer containing donor block to an empty recipient paraffin block. The use of archived remnants of diagnostic tissues for TMA manufacturing, their analysis for research purposes, and patient data were conducted according to local laws (HmbKHG, $\S 12$ ) and the analysis had been approved by the local ethics committee (Ethics commission Hamburg, WF-049/09). All work has been carried out in compliance with the Helsinki Declaration.

Immunohistochemistry (IHC). Freshly cut TMA sections were all immunostained on one day and in one experiment. Slides were deparaffinized and exposed to heat-induced antigen retrieval for $5 \mathrm{~min}$ in an autoclave at $121^{\circ} \mathrm{C}$ in a pH 7.8 TRIS-EDTA-citrate buffer. The primary antibody specific to arginase- 1 (rabbit recombinant, MSVA-511R, MS Validated Antibodies, GmbH, Hamburg, Germany) was applied at $37^{\circ} \mathrm{C}$ for $60 \mathrm{~min}$ at a dilution of 1: 150 in antibody diluent from Agilent/Dako \#S080938. The bound antibody was then visualized using the EnVision Kit (Agilent/Dako \#K5007) according to the manufacturer's directions. For tumor tissues, the percentage of positive neoplastic cells was estimated, and the staining intensity was semi-quantitatively recorded $(0,1+, 2+, 3+)$. For statistical analyses, the staining results were categorized into four groups. Tumors without any staining were considered negative. Tumors with $1+$ staining intensity in $\leq 70 \%$ of cells or $2+$ intensity in $\leq 30 \%$ of cells were considered weakly positive. Tumors with $1+$ staining 
intensity in $>70 \%$ of cells, $2+$ intensity in $31-70 \%$, or $3+$ intensity in $\leq 30 \%$ were considered moderately positive. Tumors with $2+$ intensity in $>70 \%$ or $3+$ intensity in $>30 \%$ of cells were considered strongly positive. For antibody validation, the normal tissue TMA was also stained with a second anti-arginase-1 antibody (Cell Marque clone SP156, Cat. \# 380R-18) for $20 \mathrm{~min}$, at a dilution of 1:6.25 in a Dako Link48 autostainer after Flex-high antigen retrieval.

Statistics. Statistical calculations were performed with JMP 14 software (SAS Institute Inc., Cary, NC 27513, USA). The chi ${ }^{2}$-test was performed to search for associations between arginase immunostaining and a tumor phenotype in squamous cell cancers.

\section{Results}

\subsection{Technical Issues}

A total of 12,047 (81\%) of 14,912 tumor samples were interpretable in our TMA analysis. Non-interpretable samples demonstrated a lack of unequivocal tumor cells or loss of tissue location during technical procedures. Sufficient numbers of samples of each normal tissue type were evaluable.

\subsection{Staining Pattern in Normal Tissues}

The Arginase- 1 immunostaining was typically cytoplasmic and nuclear. By far the strongest Arginase-1 immunostaining was seen in hepatocytes. Moderate to strong cytoplasmic and nuclear arginase immunostaining also occurred in the granular cell layer of keratinizing squamous epithelium of the skin. Moderate staining occurred in granulocytes and its precursor cells in the bone marrow. A weak to moderate Arginase-1 positivity was seen in a fraction of the decidua cells. Representative images are shown in Figure 1. Arginase-1 immunostaining was not observed in any other epithelial cells from the gastrointestinal tract, urothelium, non-keratinizing squamous epithelia, pancreas, salivary glands, thyroid, parathyroid gland, adenohypophysis, adrenal gland, prostate, epididymis, testis, seminal vesicle, endometrium, endocervix, fallopian tube, kidney, respiratory epithelium, lung, placenta, various types of muscle cells, myometrium, lymphatic organs, endothelium, brain and neurohypophysis. All positive stainings were also confirmed by the use of a second independent antibody (Cell Marque clone SP156, Supplementary Materials Figure S1).

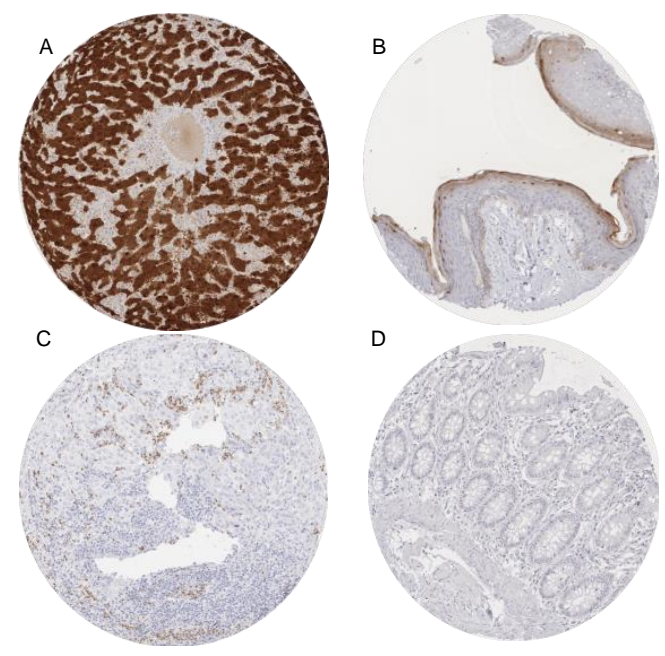

Figure 1. Arginase-1 immunostaining in normal cells. The panels show a strong cytoplasmic and nuclear arginase-1 positivity of hepatocytes (A). Hepatocyte staining is strong enough that some staining is also seen in the adjacent stroma (contamination artifact). A weak to moderate cytoplasmic and nuclear arginase-1 immunostaining occurs in the granular cell layer of the keratinizing squamous epithelium of the skin (B) while staining is weak and cytoplasmic in granulocytes infiltrating an arginase-1 negative cholangiocellular carcinoma (C). Arginase- 1 immunostaining is absent in colon epithelium (D). Magnification 100×, TMA spot size $600 \mu \mathrm{m}$. 


\subsection{Arginase in Cancer}

Arginase expression was predominantly observed in hepatocellular carcinoma, where $88 \%$ of 49 tumors showed a strong arginase positivity and $96 \%$ a moderate arginase positivity independently from the tumor stage $(p=0.4132)$. A characteristic nuclear and cytoplasmic staining was typically seen in these tumors. Although 22 additional tumor categories showed arginase immunostaining in a much smaller fraction of cases, strong and even moderate arginase- 1 staining was exceedingly rare in these entities (Table 1).

Table 1. Arginase-1 immunostaining in human tumors.

\begin{tabular}{|c|c|c|c|c|c|c|c|}
\hline & \multirow[b]{2}{*}{ Tumor Entity } & \multirow[b]{2}{*}{$\begin{array}{c}\text { On TMA } \\
\text { (n) }\end{array}$} & \multicolumn{5}{|c|}{ Arginase-1 Immunostaining } \\
\hline & & & $\begin{array}{l}\text { Analyzable } \\
\text { (n) }\end{array}$ & $\begin{array}{l}\text { Negative } \\
(\%)\end{array}$ & Weak (\%) & $\begin{array}{l}\text { Moderate } \\
(\%)\end{array}$ & $\begin{array}{c}\text { Strong } \\
(\%)\end{array}$ \\
\hline \multirow{6}{*}{$\begin{array}{l}\text { Tumors of the } \\
\text { skin }\end{array}$} & Pilomatrixoma & 35 & 33 & 97.0 & 3.0 & 0.0 & 0.0 \\
\hline & Basal cell carcinoma & 88 & 50 & 100.0 & 0.0 & 0.0 & 0.0 \\
\hline & Benign nevus & 29 & 26 & 100.0 & 0.0 & 0.0 & 0.0 \\
\hline & Squamous cell carcinoma of the skin & 90 & 77 & 85.7 & 13.0 & 1.3 & 0.0 \\
\hline & Malignant melanoma & 48 & 43 & 100.0 & 0.0 & 0.0 & 0.0 \\
\hline & Merkel cell carcinoma & 46 & 41 & 100.0 & 0.0 & 0.0 & 0.0 \\
\hline \multirow{5}{*}{$\begin{array}{l}\text { Tumors of the } \\
\text { head and neck }\end{array}$} & Squamous cell carcinoma of the larynx & 110 & 93 & 90.3 & 5.4 & 4.3 & 0.0 \\
\hline & Squamous cell carcinoma of the pharynx & 60 & 44 & 90.9 & 9.1 & 0.0 & 0.0 \\
\hline & $\begin{array}{l}\text { Oral squamous cell carcinoma (floor of } \\
\text { the mouth) }\end{array}$ & 130 & 115 & 92.2 & 7.0 & 0.9 & 0.0 \\
\hline & Pleomorphic adenoma of the parotid gland & 50 & 45 & 97.8 & 2.2 & 0.0 & 0.0 \\
\hline & Warthin tumor of the parotid gland & 49 & 49 & 100.0 & 0.0 & 0.0 & 0.0 \\
\hline \multirow{8}{*}{$\begin{array}{l}\text { Tumors of the } \\
\text { lung, pleura and } \\
\text { thymus }\end{array}$} & Basal cell adenoma of the salivary gland & 15 & 14 & 100.0 & 0.0 & 0.0 & 0.0 \\
\hline & Adenocarcinoma of the lung & 196 & 169 & 100.0 & 0.0 & 0.0 & 0.0 \\
\hline & Squamous cell carcinoma of the lung & 80 & 68 & 98.5 & 1.5 & 0.0 & 0.0 \\
\hline & Small cell carcinoma of the lung & 16 & 16 & 100.0 & 0.0 & 0.0 & 0.0 \\
\hline & Mesothelioma, epithelioid & 39 & 33 & 100.0 & 0.0 & 0.0 & 0.0 \\
\hline & Mesothelioma, other types & 76 & 63 & 100.0 & 0.0 & 0.0 & 0.0 \\
\hline & Thymoma & 29 & 29 & 100.0 & 0.0 & 0.0 & 0.0 \\
\hline & Squamous cell carcinoma of the vagina & 78 & 63 & 95.2 & 4.8 & 0.0 & 0.0 \\
\hline \multirow{12}{*}{$\begin{array}{l}\text { Tumors of the } \\
\text { female genital } \\
\text { tract }\end{array}$} & Squamous cell carcinoma of the vulva & 130 & 114 & 86.0 & 13.2 & 0.9 & 0.0 \\
\hline & Squamous cell carcinoma of the cervix & 129 & 119 & 99.2 & 0.8 & 0.0 & 0.0 \\
\hline & Endometrioid endometrial carcinoma & 236 & 222 & 100.0 & 0.0 & 0.0 & 0.0 \\
\hline & Endometrial serous carcinoma & 82 & 73 & 100.0 & 0.0 & 0.0 & 0.0 \\
\hline & Carcinosarcoma of the uterus & 48 & 41 & 100.0 & 0.0 & 0.0 & 0.0 \\
\hline & Endometrial carcinoma, high grade, G3 & 13 & 13 & 100.0 & 0.0 & 0.0 & 0.0 \\
\hline & Endometrial clear cell carcinoma & 8 & 7 & 100.0 & 0.0 & 0.0 & 0.0 \\
\hline & Endometrioid carcinoma of the ovary & 110 & 90 & 100.0 & 0.0 & 0.0 & 0.0 \\
\hline & Serous carcinoma of the ovary & 559 & 455 & 100.0 & 0.0 & 0.0 & 0.0 \\
\hline & Mucinous carcinoma of the ovary & 96 & 74 & 100.0 & 0.0 & 0.0 & 0.0 \\
\hline & Clear cell carcinoma of the ovary & 50 & 40 & 92.5 & 7.5 & 0.0 & 0.0 \\
\hline & Carcinosarcoma of the ovary & 47 & 39 & 100.0 & 0.0 & 0.0 & 0.0 \\
\hline \multirow{8}{*}{$\begin{array}{c}\text { Tumors of the } \\
\text { breast }\end{array}$} & Brenner tumor & 9 & 9 & 100.0 & 0.0 & 0.0 & 0.0 \\
\hline & Invasive breast carcinoma of no special type & 1345 & 1208 & 100.0 & 0.0 & 0.0 & 0.0 \\
\hline & Lobular carcinoma of the breast & 293 & 252 & 99.6 & 0.4 & 0.0 & 0.0 \\
\hline & Medullary carcinoma of the breast & 26 & 26 & 100.0 & 0.0 & 0.0 & 0.0 \\
\hline & Tubular carcinoma of the breast & 27 & 26 & 100.0 & 0.0 & 0.0 & 0.0 \\
\hline & Mucinous carcinoma of the breast & 58 & 49 & 98.0 & 2.0 & 0.0 & 0.0 \\
\hline & Phyllodes tumor of the breast & 50 & 50 & 100.0 & 0.0 & 0.0 & 0.0 \\
\hline & Adenomatous polyp, low-grade dysplasia & 50 & 48 & 100.0 & 0.0 & 0.0 & 0.0 \\
\hline \multirow{12}{*}{$\begin{array}{l}\text { Tumors of the } \\
\text { digestive system }\end{array}$} & Adenomatous polyp, high-grade dysplasia & 50 & 48 & 100.0 & 0.0 & 0.0 & 0.0 \\
\hline & Adenocarcinoma of the colon & 1882 & 1610 & 99.5 & 0.3 & 0.1 & 0.1 \\
\hline & Gastric adenocarcinoma, diffuse type & 176 & 142 & 100.0 & 0.0 & 0.0 & 0.0 \\
\hline & Gastric adenocarcinoma, intestinal type & 174 & 132 & 100.0 & 0.0 & 0.0 & 0.0 \\
\hline & Gastric adenocarcinoma, mixed type & 62 & 52 & 100.0 & 0.0 & 0.0 & 0.0 \\
\hline & Adenocarcinoma of the esophagus & 83 & 61 & 100.0 & 0.0 & 0.0 & 0.0 \\
\hline & Squamous cell carcinoma of the esophagus & 75 & 38 & 97.4 & 2.6 & 0.0 & 0.0 \\
\hline & Squamous cell carcinoma of the anal canal & 89 & 73 & 94.5 & 4.1 & 1.4 & 0.0 \\
\hline & Cholangiocarcinoma & 113 & 103 & 99.0 & 1.0 & 0.0 & 0.0 \\
\hline & Hepatocellular carcinoma & 50 & 49 & 4.1 & 0.0 & 8.2 & 87.8 \\
\hline & Ductal adenocarcinoma of the pancreas & 612 & 470 & 100.0 & 0.0 & 0.0 & 0.0 \\
\hline & Pancreatic/Ampullary adenocarcinoma & 89 & 77 & 100.0 & 0.0 & 0.0 & 0.0 \\
\hline \multirow{10}{*}{$\begin{array}{l}\text { Tumors of the } \\
\text { urinary system }\end{array}$} & Acinar cell carcinoma of the pancreas & 16 & 14 & 100.0 & 0.0 & 0.0 & 0.0 \\
\hline & Gastrointestinal stromal tumor (GIST) & 50 & 49 & 100.0 & 0.0 & 0.0 & 0.0 \\
\hline & Urothelial carcinoma, pT2-4 G3 & 1206 & 588 & 99.8 & 0.2 & 0.0 & 0.0 \\
\hline & $\begin{array}{c}\text { Small cell neuroendocrine carcinoma of } \\
\text { the bladder }\end{array}$ & 20 & 19 & 100.0 & 0.0 & 0.0 & 0.0 \\
\hline & Sarcomatoid urothelial carcinoma & 25 & 24 & 100.0 & 0.0 & 0.0 & 0.0 \\
\hline & Clear cell renal cell carcinoma & 857 & 644 & 100.0 & 0.0 & 0.0 & 0.0 \\
\hline & Papillary renal cell carcinoma & 255 & 185 & 100.0 & 0.0 & 0.0 & 0.0 \\
\hline & Clear cell (tubulo) papillary renal cell carcinoma & 21 & 16 & 100.0 & 0.0 & 0.0 & 0.0 \\
\hline & Chromophobe renal cell carcinoma & 131 & 107 & 100.0 & 0.0 & 0.0 & 0.0 \\
\hline & Oncocytoma & 177 & 130 & 100.0 & 0.0 & 0.0 & 0.0 \\
\hline
\end{tabular}


Table 1. Cont.

\begin{tabular}{|c|c|c|c|c|c|c|c|}
\hline & \multirow[b]{2}{*}{ Tumor Entity } & \multirow[b]{2}{*}{$\underset{\text { (n) }}{\text { On TMA }}$} & \multicolumn{5}{|c|}{ Arginase-1 Immunostaining } \\
\hline & & & $\begin{array}{l}\text { Analyzable } \\
\text { (n) }\end{array}$ & $\begin{array}{l}\text { Negative } \\
(\%)\end{array}$ & Weak (\%) & $\begin{array}{l}\text { Moderate } \\
(\%)\end{array}$ & $\begin{array}{c}\text { Strong } \\
(\%)\end{array}$ \\
\hline \multirow{9}{*}{$\begin{array}{l}\text { Tumors of the } \\
\text { male genital } \\
\text { organs }\end{array}$} & Adenocarcinoma of the prostate, Gleason $3+3$ & 83 & 80 & 100.0 & 0.0 & 0.0 & 0.0 \\
\hline & Adenocarcinoma of the prostate, Gleason $4+4$ & 80 & 72 & 100.0 & 0.0 & 0.0 & 0.0 \\
\hline & Adenocarcinoma of the prostate, Gleason $5+5$ & 85 & 78 & 100.0 & 0.0 & 0.0 & 0.0 \\
\hline & Adenocarcinoma of the prostate (recurrence) & 258 & 211 & 98.1 & 1.4 & 0.5 & 0.0 \\
\hline & $\begin{array}{l}\text { Small cell neuroendocrine carcinoma of } \\
\text { the prostate }\end{array}$ & 19 & 17 & 100.0 & 0.0 & 0.0 & 0.0 \\
\hline & Seminoma & 621 & 446 & 100.0 & 0.0 & 0.0 & 0.0 \\
\hline & Embryonal carcinoma of the testis & 50 & 35 & 100.0 & 0.0 & 0.0 & 0.0 \\
\hline & Yolk sac tumor & 50 & 31 & 100.0 & 0.0 & 0.0 & 0.0 \\
\hline & Teratoma & 50 & 46 & 95.7 & 4.3 & 0.0 & 0.0 \\
\hline \multirow{18}{*}{$\begin{array}{c}\text { Tumors of } \\
\text { endocrine organs }\end{array}$} & Squamous cell carcinoma of the penis & 80 & 63 & 92.1 & 7.9 & 0.0 & 0.0 \\
\hline & Adenoma of the thyroid gland & 114 & 104 & 100.0 & 0.0 & 0.0 & 0.0 \\
\hline & Papillary thyroid carcinoma & 392 & 351 & 100.0 & 0.0 & 0.0 & 0.0 \\
\hline & Follicular thyroid carcinoma & 154 & 136 & 100.0 & 0.0 & 0.0 & 0.0 \\
\hline & Medullary thyroid carcinoma & 111 & 100 & 100.0 & 0.0 & 0.0 & 0.0 \\
\hline & Anaplastic thyroid carcinoma & 45 & 43 & 100.0 & 0.0 & 0.0 & 0.0 \\
\hline & Adrenal cortical adenoma & 50 & 21 & 100.0 & 0.0 & 0.0 & 0.0 \\
\hline & Adrenal cortical carcinoma & 26 & 26 & 100.0 & 0.0 & 0.0 & 0.0 \\
\hline & Phaeochromocytoma & 50 & 50 & 100.0 & 0.0 & 0.0 & 0.0 \\
\hline & Appendix, neuroendocrine tumor (NET) & 22 & 13 & 100.0 & 0.0 & 0.0 & 0.0 \\
\hline & Colorectal, neuroendocrine tumor (NET) & 12 & 11 & 100.0 & 0.0 & 0.0 & 0.0 \\
\hline & Ileum, neuroendocrine tumor (NET) & 49 & 45 & 100.0 & 0.0 & 0.0 & 0.0 \\
\hline & Lung, neuroendocrine tumor (NET) & 19 & 17 & 100.0 & 0.0 & 0.0 & 0.0 \\
\hline & Pancreas, neuroendocrine tumor (NET) & 97 & 93 & 95.7 & 2.2 & 2.2 & 0.0 \\
\hline & Colorectal, neuroendocrine carcinoma (NEC) & 12 & 10 & 100.0 & 0.0 & 0.0 & 0.0 \\
\hline & Gallbladder, neuroendocrine carcinoma (NEC) & 4 & 4 & 100.0 & 0.0 & 0.0 & 0.0 \\
\hline & Pancreas, neuroendocrine carcinoma (NEC) & 14 & 14 & 100.0 & 0.0 & 0.0 & 0.0 \\
\hline & Hodgkin Lymphoma & 103 & 72 & 100.0 & 0.0 & 0.0 & 0.0 \\
\hline \multirow{7}{*}{$\begin{array}{c}\text { Tumors of } \\
\text { haematopoietic } \\
\text { and lymphoid } \\
\text { tissues }\end{array}$} & $\begin{array}{l}\text { Small lymphocytic lymphoma, B-cell type } \\
\text { (B-SLL/B-CLL) }\end{array}$ & 50 & 29 & 100.0 & 0.0 & 0.0 & 0.0 \\
\hline & Diffuse large B cell lymphoma (DLBCL) & 114 & 95 & 100.0 & 0.0 & 0.0 & 0.0 \\
\hline & Follicular lymphoma & 88 & 63 & 100.0 & 0.0 & 0.0 & 0.0 \\
\hline & T-cell Non Hodgkin lymphoma & 24 & 14 & 100.0 & 0.0 & 0.0 & 0.0 \\
\hline & Mantle cell lymphoma & 18 & 14 & 100.0 & 0.0 & 0.0 & 0.0 \\
\hline & Marginal zone lymphoma & 16 & 10 & 100.0 & 0.0 & 0.0 & 0.0 \\
\hline & $\begin{array}{l}\text { Diffuse large B-cell lymphoma (DLBCL) in } \\
\text { the testis }\end{array}$ & 16 & 13 & 100.0 & 0.0 & 0.0 & 0.0 \\
\hline \multirow{22}{*}{$\begin{array}{l}\text { Tumors of soft } \\
\text { tissue and bone }\end{array}$} & Burkitt lymphoma & 5 & 1 & 100.0 & 0.0 & 0.0 & 0.0 \\
\hline & Tenosynovial giant cell tumor & 45 & 43 & 100.0 & 0.0 & 0.0 & 0.0 \\
\hline & Granular cell tumor & 53 & 42 & 100.0 & 0.0 & 0.0 & 0.0 \\
\hline & Leiomyoma & 50 & 48 & 100.0 & 0.0 & 0.0 & 0.0 \\
\hline & Leiomyosarcoma & 87 & 81 & 100.0 & 0.0 & 0.0 & 0.0 \\
\hline & Liposarcoma & 132 & 123 & 100.0 & 0.0 & 0.0 & 0.0 \\
\hline & $\begin{array}{l}\text { Malignant peripheral nerve sheath tumor } \\
\text { (MPNST) }\end{array}$ & 13 & 12 & 100.0 & 0.0 & 0.0 & 0.0 \\
\hline & Myofibrosarcoma & 26 & 26 & 100.0 & 0.0 & 0.0 & 0.0 \\
\hline & Ángiosarcoma & 73 & 61 & 100.0 & 0.0 & 0.0 & 0.0 \\
\hline & Angiomyolipoma & 91 & 91 & 100.0 & 0.0 & 0.0 & 0.0 \\
\hline & Dermatofibrosarcoma protuberans & 21 & 18 & 100.0 & 0.0 & 0.0 & 0.0 \\
\hline & Ganglioneuroma & 14 & 13 & 100.0 & 0.0 & 0.0 & 0.0 \\
\hline & Kaposi sarcoma & 8 & 6 & 100.0 & 0.0 & 0.0 & 0.0 \\
\hline & Neurofibroma & 117 & 93 & 100.0 & 0.0 & 0.0 & 0.0 \\
\hline & Sarcoma, not otherwise specified (NOS) & 74 & 71 & 100.0 & 0.0 & 0.0 & 0.0 \\
\hline & Paraganglioma & 41 & 37 & 100.0 & 0.0 & 0.0 & 0.0 \\
\hline & Ewing sarcoma & 23 & 18 & 100.0 & 0.0 & 0.0 & 0.0 \\
\hline & Rhabdomyosarcoma & 6 & 6 & 100.0 & 0.0 & 0.0 & 0.0 \\
\hline & Schwannoma & 121 & 103 & 100.0 & 0.0 & 0.0 & 0.0 \\
\hline & Synovial sarcoma & 12 & 11 & 100.0 & 0.0 & 0.0 & 0.0 \\
\hline & Osteosarcoma & 43 & 35 & 100.0 & 0.0 & 0.0 & 0.0 \\
\hline & Chondrosarcoma & 38 & 24 & 100.0 & 0.0 & 0.0 & 0.0 \\
\hline
\end{tabular}

The focal staining of a few tumor cells was observed in squamous cell carcinomas for various sites, where it was significantly associated with a low histological tumor grade $(p=0.003$, Table 2). 
Table 2. Arginase- 1 immunostaining and tumor phenotype in 635 squamous cell carcinomas (SQCC) of various origins, including SQCC of the floor of the mouth $(n=99)$, pharynx $(n=40)$, larynx $(n=86)$, cervix $(n=116)$, vagina $(n=36)$, vulva $(n=106)$, penis $(n=59)$, skin $(n=45)$, and anal canal $(n=48)$.

\begin{tabular}{ccccccc}
\hline & \multicolumn{7}{c}{ Arginase Immunostaining in SQCC } \\
\cline { 2 - 7 } & $\mathbf{n}$ & Neg. (\%) & Weak (\%) & Mod. (\%) & Strong (\%) & $p$ \\
\hline pT1 & 220 & 93.2 & 6.4 & 0.5 & 0.0 & 0.0761 \\
pT2 & 221 & 94.6 & 5.4 & 0.0 & 0.0 & \\
pT3 & 81 & 88.9 & 7.4 & 3.7 & 0.0 & \\
pT4 & 113 & 91.2 & 6.2 & 2.7 & 0.0 & \\
pN0 & 236 & 91.9 & 6.4 & 1.7 & 0.0 & 0.6054 \\
pN+ & 233 & 94.0 & 5.2 & 0.9 & 0.0 & \\
G1 & 28 & 85.7 & 10.7 & 3.6 & 0.0 & 0.0025 \\
G2 & 340 & 90.3 & 8.5 & 1.2 & 0.0 & \\
G3 & 226 & 97.8 & 1.8 & 0.4 & 0.0 & \\
\hline
\end{tabular}

Arginase-1 staining was unrelated to HPV-status, however (Table 3).

Table 3. Arginase-1 immunostaining and HPV status in squamous cell carcinomas.

\begin{tabular}{|c|c|c|c|c|c|c|c|}
\hline & \multirow{2}{*}{$\begin{array}{c}\text { HPV } \\
\text { Status }\end{array}$} & \multirow{2}{*}{$\mathbf{n}$} & \multicolumn{4}{|c|}{ Arginase Status (\%) } & \multirow{2}{*}{$p$} \\
\hline & & & Negative & Weak & Moderate & Strong & \\
\hline \multirow{2}{*}{$\begin{array}{l}\text { All squamous } \\
\text { cell cancers }\end{array}$} & negativ & 250 & 90.0 & 8.4 & 1.6 & 0.0 & 0.7690 \\
\hline & positive & 204 & 91.7 & 7.4 & 1.0 & 0.0 & \\
\hline \multirow{2}{*}{$\begin{array}{l}\text { Oral squamous } \\
\text { cell carcinoma }\end{array}$} & negativ & 56 & 89.3 & 8.9 & 1.8 & 0.0 & 0.8193 \\
\hline & positive & 12 & 91.7 & 8.3 & 0.0 & 0.0 & \\
\hline \multirow{2}{*}{$\begin{array}{l}\text { Squamous cell } \\
\text { carcinoma of } \\
\text { the pharynx }\end{array}$} & negativ & 18 & 94.4 & 5.6 & 0.0 & 0.0 & 0.4354 \\
\hline & positive & 24 & 87.5 & 12.5 & 0.0 & 0.0 & \\
\hline \multirow[t]{2}{*}{$\begin{array}{l}\text { Squamous cell } \\
\text { carcinoma of } \\
\text { the larynx }\end{array}$} & negativ & 39 & 89.7 & 5.1 & 5.1 & 0.0 & 0.5278 \\
\hline & positive & 7 & 85.7 & 14.3 & 0.0 & 0.0 & \\
\hline \multirow[t]{2}{*}{$\begin{array}{l}\text { Squamous cell } \\
\text { carcinoma of } \\
\text { the cervix }\end{array}$} & negativ & 10 & 100.0 & 0.0 & 0.0 & 0.0 & - \\
\hline & positive & 64 & 100.0 & 0.0 & 0.0 & 0.0 & \\
\hline \multirow[t]{2}{*}{$\begin{array}{l}\text { Squamous cell } \\
\text { carcinoma of } \\
\text { the vagina }\end{array}$} & negativ & 15 & 93.3 & 6.7 & 0.0 & 0.0 & 0.2578 \\
\hline & positive & 13 & 100.0 & 0.0 & 0.0 & 0.0 & \\
\hline \multirow[t]{2}{*}{$\begin{array}{l}\text { Squamous cell } \\
\text { carcinoma of } \\
\text { the vulva }\end{array}$} & negativ & 47 & 87.2 & 12.8 & 0.0 & 0.0 & 0.1330 \\
\hline & positive & 24 & 70.8 & 25.0 & 4.2 & 0.0 & \\
\hline \multirow[t]{2}{*}{$\begin{array}{l}\text { Squamous cell } \\
\text { carcinoma of } \\
\text { the penis }\end{array}$} & negativ & 26 & 96.2 & 3.8 & 0.0 & 0.0 & 0.2657 \\
\hline & positive & 35 & 88.6 & 11.4 & 0.0 & 0.0 & \\
\hline \multirow[t]{2}{*}{$\begin{array}{l}\text { Squamous cell } \\
\text { carcinoma of } \\
\text { the skin }\end{array}$} & negativ & 34 & 85.3 & 11.8 & 2.9 & 0.0 & 0.8551 \\
\hline & positive & 1 & 100.0 & 0.0 & 0.0 & 0.0 & \\
\hline \multirow{2}{*}{$\begin{array}{l}\text { Squamous cell } \\
\text { carcinoma of the } \\
\text { anal canal }\end{array}$} & negativ & 5 & 80.0 & 20.0 & 0.0 & 0.0 & 0.1347 \\
\hline & positive & 24 & 95.8 & 0.0 & 4.2 & 0.0 & \\
\hline
\end{tabular}


Similarly to arginase expression of normal squamous epithelium, arginase positivity typically involved maturing cells at the beginning of keratinization in these tumors. Rare positive cases of teratoma, urothelial carcinoma and pleomorphic adenomas also showed arginase expression in areas with squamous differentiation. Other tumor entities with occasional and mostly low-level arginase-1 immunostaining included clear cell carcinomas of the ovary, neuroendocrine tumors of the pancreas, mucinous and lobular carcinoma of the breast, cholangiocarcinoma, and colorectal adenocarcinoma. In rare case of arginase positive colorectal and mucinous breast carcinomas, arginase staining predominated in the intratumoral mucus (breast) or mucin producing goblet cells (colon). Representative images of arginase immunostaining in cancers are presented in Figure 2. A ranking order of arginase-1 positive and strongly positive cases in combination, with a summary of data from comparable studies, is provided in Figure 3.
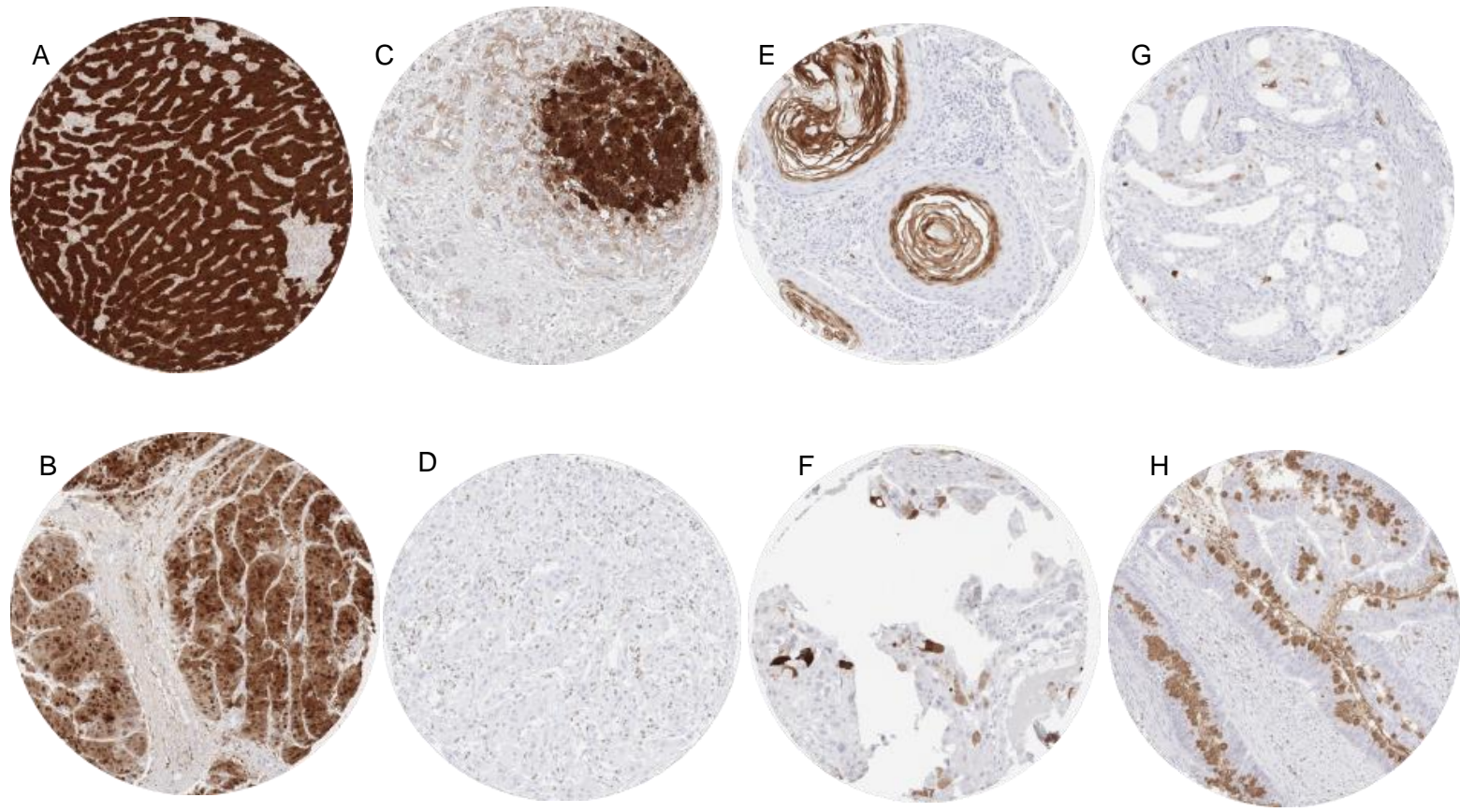

Figure 2. Arginase-1 immunostaining in cancer. The panels show examples of a strong (A) and a more variable, moderate to strong (B) nuclear and cytoplasmic arginase-1 staining in hepatocellular carcinomas. A weak and purely cytoplasmic arginase-1 staining in a cholangiocellular carcinoma (C) which is particularly seen in cells adjacent to strongly positive normal hepatocytes may reflect a "contamination" artifact. In another cholangiocellular carcinoma, tumor cells are arginase1 negative, and staining is limited to tumor-associated granulocytes (D). A focal arginase- 1 immunostaining is seen in keratinizing cells of a pharyngeal squamous cell carcinoma (E), a clear cell carcinoma of the ovary (F), and a Gleason $4+4=8$ adenocarcinoma of the prostate $(G)$. In a colorectal adenocarcinoma arginase- 1 staining occurs in goblet cells and tumor-associated mucins (H). Magnification 100×, TMA spot size $600 \mu \mathrm{m}$. 


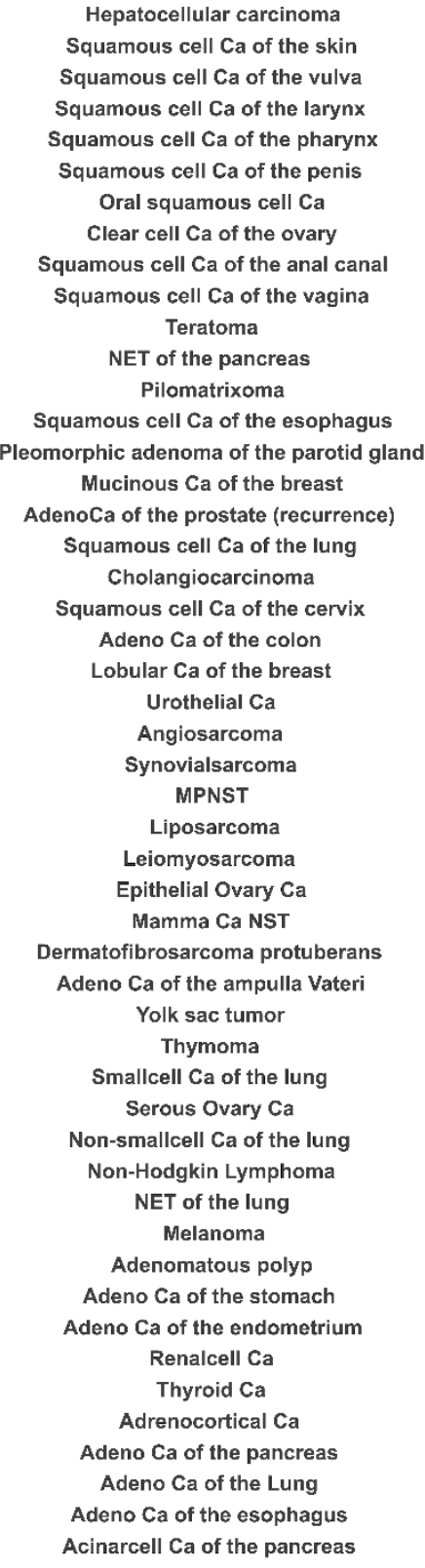

Hepatocellular carcinoma Squamous cell Ca of the skin Squamous cell $\mathrm{Ca}$ of the larynx Squamous cell $\mathrm{Ca}$ of the pharynx quamous cell $\mathrm{Ca}$ of the penis Oral squamous cell $\mathrm{Ca}$ quamous cell $\mathrm{Ca}$ of the anal canal Teratoma T of the pancreas Pilomatrixoma Squamous cell $\mathrm{Ca}$ of the esophagus
Pleomorphic adenoma of the parotid gland Mucinous $\mathrm{Ca}$ of the breast cell $\mathrm{Ca}$ of the lung amous cell $\mathrm{Ca}$ of the cervix Adeno $\mathrm{Ca}$ of the colon novialsarcoma pithelial Ovary $\mathrm{Ca}$

rmatofibrosarcoma protuberans Yolk sac tumor llcell $\mathrm{Ca}$ of the lun smallcell $\mathrm{Ca}$ of the lun gkin Lymphom Melanoma

Adenomatous poly

a of the stomach Renalcell Ca Thyroid Ca eno $\mathrm{Ca}$ of the pancreas Adeno $\mathrm{Ca}$ of the esophagus

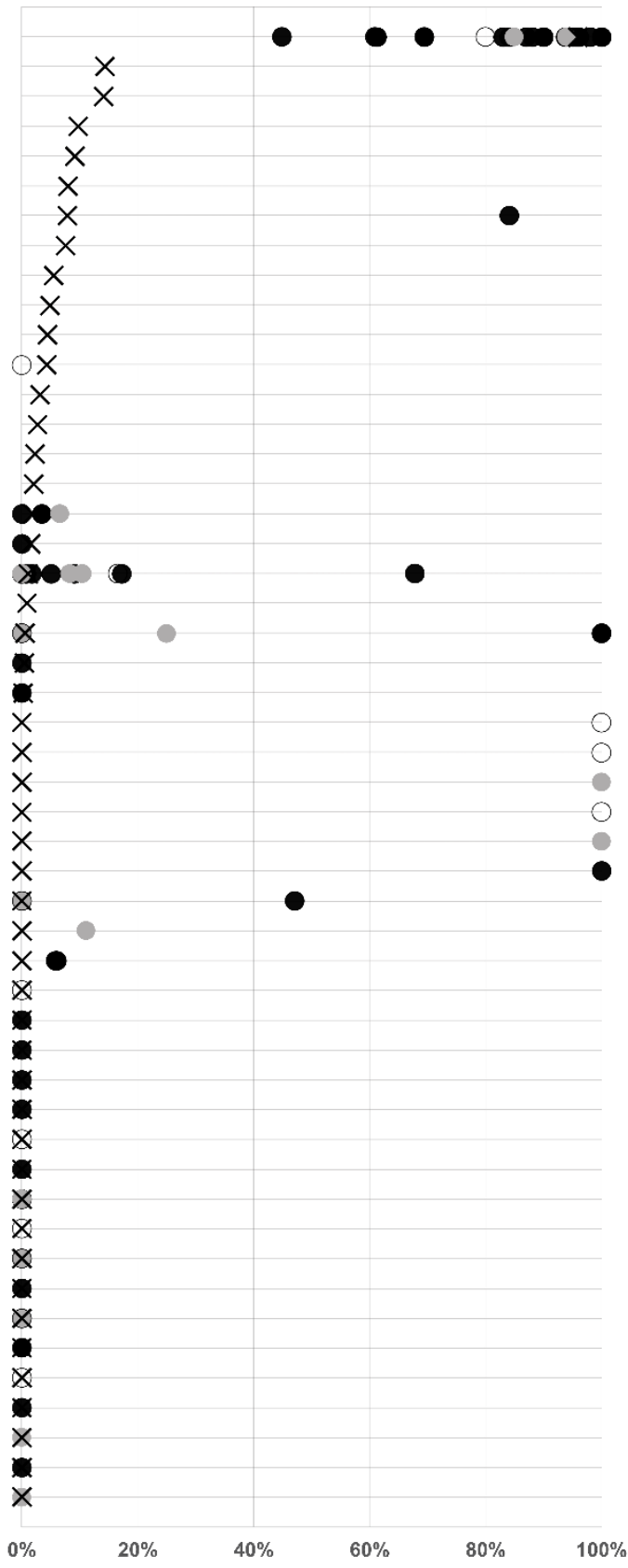

Figure 3. Graphical comparison of Arginase data from this study $(x)$ in comparison with the previous literature (dots). Open: $n=1-10$, grey: $n=11-25$, black: $n>25$. For comparison purposes, studies that did not differentiate between different tumor subtypes were marked with black dots and the overall positivity rate was applied to the different tumor subtypes present in our tumor microarrays. All studies are referred to in the reference list.

\section{Discussion}

Given the large scale of our study, we placed emphasis on the thorough validation of our assay. The International Working Group for Antibody Validation (IWGAV) proposed that antibody validation for immunohistochemistry on formalin fixed tissues should include either a comparison of the findings obtained by two different independent antibodies, or a comparison with expression data obtained by another independent method [37]. To ensure that any antibody cross reactivity would be detected in our validation experiment, a broad range of different normal tissue categories were included in the analysis and the immunohistochemical staining results were not only compared with a second independent 
antibody, but also with RNA expression data derived from three independent RNA screening studies, including the Human Protein Atlas (HPA) RNA-seq tissue dataset [38], the FANTOM5 project [39,40], and the Genotype-Tissue Expression (GTEx) project [41]. The 76 different normal tissues that were selected for this experiment are likely to contain the majority of proteins occurring in the cells of adult humans. Therefore, we consider it likely that undesired antibody cross-reactivity can be detected with high certainty. A specific antibody reactivity in our experimental set-up is supported by the detection of significant arginase-1 immunostaining in all organs, with documented arginase-1 RNA expression (liver, skin, bone marrow, and granulocytes). The fact that RNA expression had not previously been documented for decidua cells is not surprising, given the paucity of these cells in mature placenta tissue samples that were systematically screened for RNA expression. True arginase-1 expression in decidua cells is, however, supported by the comparison with the independent antibody Cell Marque clone SP156, which also confirmed liver, skin, bone marrow and granulocyte staining (Supplementary Materials Figure S1).

A successful analysis of 12,047 cancers from 117 different tumor entities revealed a pattern of expression for arginase- 1 that strongly correlated with the findings in normal tissues. Additionally, Arginase-1 expression was commonly seen in hepatocellular carcinomas, maturing/keratinizing zones of squamous cell carcinomas and in tumor infiltrating granulocytes. These findings greatly support the use of using arginase- 1 immunohistochemistry for corroborating a suspected diagnosis of hepatocellular carcinoma. That $88 \%$ of 49 successfully analyzed HCC showed a strong arginase- 1 immunostaining and 96\% showed a moderate staining fits well with earlier data. Of the 21 studies analyzing arginase1 in hepatocellular carcinoma 9 described positivity rates of $>90 \%[10,13,16-19,23,25]$. That some studies also reported arginase-1 positivity rates of $44.9 \%$ [22], 80\% [15] and 84\% [14] reflects the inherent issue of incomplete reproducibility of immunostaining as long as the associated reagents and protocols are not standardized. Most of the previous studies agree that the few arginase- 1 negative hepatocellular carcinomas are often poorly differentiated $[8,12,22,26]$.

It is of note that the experimental set-up of this study resulted in some diffuse weak to moderate staining of stroma as well as of tumor tissue adjacent to strongly arginase-1 positive normal liver cells. This staining is likely to represent a contamination artifact due to the potential diffusion of abundant arginase- 1 from the hepatocytes to adjacent tissue. Such a diffusion of abundant proteins may be facilitated by tissue damage, which can, for example, be caused by prolonged tissue ischemia before fixation occurs. Comparable artifacts occur, for example, in the thyroid, where some thyroglobulin immunostaining of medullary carcinomas can be observed in areas adjacent to normal follicles that contain abundant thyroglobulin [42]. The one arginase-1 positive cholangiocellular carcinoma of the liver showed a weak cytoplasmic staining for approximately $25 \%$ of the cells, which we accepted as "arginase- 1 positive" because of the absence of strongly positive liver cells in this sample. If we had disregarded a weak to moderate arginase- 1 immunostaining limited to the cytoplasm (non-nuclear) in samples from the liver, we would not have recorded any arginase- 1 positivity in cholangiocellular carcinomas. In addition, our study did not reveal signs of intratumoral heterogeneity of arginase staining, although this aspect was not systematically addressed. It seems possible that a variable interpretation of such findings has contributed to the high variability of published data on arginase-1 positivity in cholangiocarcinoma, ranging from $0 \%$ [8] to $68 \%$ [31]. The pattern of arginase1 immunostaining in squamous cell carcinomas closely resembled the findings in the normal keratinizing squamous epithelium. Arginase- 1 positivity is focal in squamous cell carcinomas and tightly linked to a distinct maturation stage of the epithelium which is comparable to the granular layer of the normal squamous epithelium. As keratinization represents a feature of more mature squamous epithelium, it is not surprising that arginase1 positivity was statistically linked to well-differentiated squamous cell carcinomas in this study. 
Arginase-1 positivity was only very rarely observed in non-hepatocellular, nonsquamous cell carcinomas. In some of these cases, arginase- 1 positivity occurred in areas of squamous differentiation (urothelial carcinoma, pleomorphic adenoma) or in the keratinizing squamous epithelium of a testicular teratoma. That a focal-mostly weak-arginase- 1 immunostaining could also occasionally be seen in mucus producing cells of colorectal adenocarcinomas, clear cell carcinoma of the ovary, mucinous and lobular breast cancer may reflect the fact that genes without a cancer promoting function may be randomly activated in cancer cells $[43,44]$.

In summary, these data show that strong nuclear and cytoplasmic arginase- 1 immunostaining is largely specific for tumors of hepatocellular origin. The most significant issue to consider from a diagnostic point of view is the possibility of a contamination artifact in non-arginase-1 expressing tumor cells, adjacent to strongly arginase-1 positive normal liver cells. Furthermore, Arginase-1 positivity is also common in squamous cell carcinomas but limited to areas at the beginning of keratinization in these tumors.

Supplementary Materials: The following are available online at https://www.mdpi.com/article/ 10.3390/diagnostics11122351/s1, Supplementary Figure S1: Antibody validation by comparison of antibodies. The panels show a complete concordance of staining results obtained by two independent arginase-1 antibodies. Using MSVA-511R, there was a strong nuclear and cytoplasmic staining of hepatocytes (A) and weak to moderate nuclear and cytoplasmic staining of the granular layer of keratinizing squamous epithelium of the skin (B,C). Using Cell Marque clone SP156, nearly identical staining is seen in hepatocytes (D), and the skin (E,F). The images (A-C) and (D-F) were taken from consecutive tissue sections. Magnification 100×, TMA spot size $600 \mu \mathrm{m}$.

Author Contributions: M.L., R.S., G.S., R.U. contributed to conception, design, data collection, data analysis and manuscript writing. E.G., A.M., F.B., D.H., S.W., A.H.M., E.B., T.S.C., W.W., C.B., P.L., T.K., S.S., D.D. participated in pathology data analysis and data interpretation. A.H., V.R., C.F., R.U., N.G., F.J. and S.M. immunohistochemistry analysis. A.H.M., T.K. conception and design, collection of samples. C.H.-M. and R.S. performed statistical analysis. M.L., R.U., R.S., G.S. study supervision. All authors agree to be accountable for the content of the work. All authors have read and agreed to the published version of the manuscript.

Funding: This research received no external funding.

Institutional Review Board Statement: The usage of archived diagnostic left-over tissues for manufacturing of TMAs and their analysis for research purposes as well as patient data analysis has been approved by local laws (HmbKHG, §12,1) and by the local ethics committee (Ethics commission Hamburg, WF-049/09). All work was carried out in compliance with the Helsinki Declaration.

Informed Consent Statement: Patient consent was waived due to local laws (HmbKHG, §12,1) that permit research with anonymized diagnostic left-over tissue samples.

Data Availability Statement: Raw data are available upon reasonable request. All data relevant to the study are included in the article.

Acknowledgments: We are grateful to Melanie Witt, Inge Brandt, Maren Eisenberg, and Sünje Seekamp for excellent technical assistance.

Conflicts of Interest: The arginase-1 antibody (rabbit recombinant, MSVA-511R) was provided from MS Validated Antibodies GmbH (owned by a family member of GS).

\section{References}

1. Clemente, G.S.; van Waarde, A.; Antunes, I.F.; Domling, A.; Elsinga, P.H. Arginase as a Potential Biomarker of Disease Progression: A Molecular Imaging Perspective. Int. J. Mol. Sci. 2020, 21, 5291. [CrossRef] [PubMed]

2. Di Costanzo, L.; Moulin, M.; Haertlein, M.; Meilleur, F.; Christianson, D.W. Expression, purification, assay, and crystal structure of perdeuterated human arginase I. Arch. Biochem. Biophys. 2007, 465, 82-89. [CrossRef]

3. Christianson, D.W. Arginase: Structure, mechanism, and physiological role in male and female sexual arousal. Acc. Chem. Res. 2005, 38, 191-201. [CrossRef] [PubMed]

4. Nguyen, J.; Charmley, P.; Grody, W.W.; Cederbaum, S.D.; King, M.C.; Gatti, R.A. Genetic linkage group (ARG1-D6S33-MYB) on chromosome 6q containing the arginase-1 and MYB genes. Cytogenet. Cell Genet. 1990, 54, 95-96. [CrossRef] 
5. Takahashi, Y.; Dungubat, E.; Kusano, H.; Ganbat, D.; Tomita, Y.; Odgerel, S.; Fukusato, T. Application of Immunohistochemistry in the Pathological Diagnosis of Liver Tumors. Int. J. Mol. Sci. 2021, 22, 5780. [CrossRef]

6. Lu, S.X.; Huang, Y.H.; Liu, L.L.; Zhang, C.Z.; Yang, X.; Yang, Y.Z.; Shao, C.K.; Li, J.M.; Xie, D.; Zhang, X.; et al. alpha-Fetoprotein mRNA in situ hybridisation is a highly specific marker of hepatocellular carcinoma: A multi-centre study. Br. J. Cancer 2021, 124, 1988-1996. [CrossRef]

7. Moudi, B.; Mahmoudzadeh-Sagheb, H.; Heidari, Z. Hepatocyte paraffin 1 and arginase-1 are effective panel of markers in HBV-related HCC diagnosis in fine-needle aspiration specimens. BMC Res. Notes 2020, 13, 388. [CrossRef]

8. Obiorah, I.E.; Chahine, J.; Park, B.U.; Ko, K.; deGuzman, J.; Kallakury, B. Well differentiated arginase-1 negative hepatocellular carcinoma. Transl. Gastroenterol. Hepatol. 2019, 4, 66. [CrossRef] [PubMed]

9. Labib, O.H.; Harb, O.A.; Khalil, O.H.; Baiomy, T.A.; Gertallah, L.M.; Ahmed, R.Z. The Diagnostic Value of Arginase-1, FTCD, and MOC-31 Expression in Early Detection of Hepatocellular Carcinoma (HCC) and in Differentiation Between HCC and Metastatic Adenocarcinoma to the Liver. J. Gastrointest. Cancer 2020, 51, 88-101. [CrossRef] [PubMed]

10. You, J.; Chen, W.; Chen, J.; Zheng, Q.; Dong, J.; Zhu, Y. The Oncogenic Role of ARG1 in Progression and Metastasis of Hepatocellular Carcinoma. Biomed. Res. Int. 2018, 2018, 2109865. [CrossRef]

11. Zhao, C.L.; Hui, Y.; Wang, L.J.; Yang, D.; Yakirevich, E.; Mangray, S.; Huang, C.K.; Lu, S. Alanine-glyoxylate aminotransferase 1 (AGXT1) is a novel marker for hepatocellular carcinomas. Hum. Pathol. 2018, 80, 76-81. [CrossRef]

12. Clark, I.; Shah, S.S.; Moreira, R.; Graham, R.P.; Wu, T.T.; Torbenson, M.S.; Chandan, V. A subset of well-differentiated hepatocellular carcinomas are Arginase-1 negative. Hum. Pathol. 2017, 69, 90-95. [CrossRef] [PubMed]

13. Fujikura, K.; Yamasaki, T.; Otani, K.; Kanzawa, M.; Fukumoto, T.; Ku, Y.; Hirose, T.; Itoh, T.; Zen, Y. BSEP and MDR3: Useful Immunohistochemical Markers to Discriminate Hepatocellular Carcinomas From Intrahepatic Cholangiocarcinomas and Hepatoid Carcinomas. Am. J. Surg. Pathol. 2016, 40, 689-696. [CrossRef]

14. Srivastava, S.; Ghosh, S.K. Modulation of L-Arginine-Arginase Metabolic Pathway Enzymes: Immunocytochemistry and mRNA Expression in Peripheral Blood and Tissue Levels in Head and Neck Squamous Cell Carcinomas in North East India. Asian Pac. J. Cancer Prev. 2015, 16, 7031-7038. [CrossRef]

15. Salleng, K.J.; Revetta, F.L.; Deane, N.G.; Washington, M.K. The Applicability of a Human Immunohistochemical Panel to Mouse Models of Hepatocellular Neoplasia. Comp. Med. 2015, 65, 398-408.

16. Geramizadeh, B.; Seirfar, N. Diagnostic Value of Arginase-1 and Glypican-3 in Differential Diagnosis of Hepatocellular Carcinoma, Cholangiocarcinoma and Metastatic Carcinoma of Liver. Hepat. Mon. 2015, 15, e30336. [CrossRef]

17. Nguyen, T.; Phillips, D.; Jain, D.; Torbenson, M.; Wu, T.T.; Yeh, M.M.; Kakar, S. Comparison of 5 Immunohistochemical Markers of Hepatocellular Differentiation for the Diagnosis of Hepatocellular Carcinoma. Arch. Pathol. Lab. Med. 2015, 139, 1028-1034. [CrossRef]

18. Sang, W.; Zhang, W.; Cui, W.; Li, X.; Abulajiang, G.; Li, Q. Arginase-1 is a more sensitive marker than HepPar-1 and AFP in differential diagnosis of hepatocellular carcinoma from nonhepatocellular carcinoma. Tumour Biol. 2015, 36, 3881-3886. [CrossRef]

19. Lagana, S.M.; Salomao, M.; Remotti, H.E.; Knisely, A.S.; Moreira, R.K. Bile salt export pump: A sensitive and specific immunohistochemical marker of hepatocellular carcinoma. Histopathology 2015, 66, 598-602. [CrossRef]

20. Shahid, M.; Mubeen, A.; Tse, J.; Kakar, S.; Bateman, A.C.; Borger, D.; Rivera, M.N.; Ting, D.T.; Deshpande, V. Branched chain in situ hybridization for albumin as a marker of hepatocellular differentiation: Evaluation of manual and automated in situ hybridization platforms. Am. J. Surg. Pathol. 2015, 39, 25-34. [CrossRef]

21. Fatima, N.; Cohen, C.; Siddiqui, M.T. Arginase-1: A highly specific marker separating pancreatic adenocarcinoma from hepatocellular carcinoma. Acta Cytol. 2014, 58, 83-88. [CrossRef]

22. Ye, Y.; Huang, A.; Huang, C.; Liu, J.; Wang, B.; Lin, K.; Chen, Q.; Zeng, Y.; Chen, H.; Tao, X.; et al. Comparative mitochondrial proteomic analysis of hepatocellular carcinoma from patients. Proteom. Clin. Appl. 2013, 7, 403-415. [CrossRef]

23. Krings, G.; Ramachandran, R.; Jain, D.; Wu, T.T.; Yeh, M.M.; Torbenson, M.; Kakar, S. Immunohistochemical pitfalls and the importance of glypican 3 and arginase in the diagnosis of scirrhous hepatocellular carcinoma. Mod. Pathol. 2013, 26, 782-791. [CrossRef]

24. Radwan, N.A.; Ahmed, N.S. The diagnostic value of arginase-1 immunostaining in differentiating hepatocellular carcinoma from metastatic carcinoma and cholangiocarcinoma as compared to HepPar-1. Diagn. Pathol. 2012, 7, 149. [CrossRef]

25. Timek, D.T.; Shi, J.; Liu, H.; Lin, F. Arginase-1, HepPar-1, and Glypican-3 are the most effective panel of markers in distinguishing hepatocellular carcinoma from metastatic tumor on fine-needle aspiration specimens. Am. J. Clin. Pathol. 2012, 138, 203-210. [CrossRef]

26. Yan, B.C.; Gong, C.; Song, J.; Krausz, T.; Tretiakova, M.; Hyjek, E.; Al-Ahmadie, H.; Alves, V.; Xiao, S.Y.; Anders, R.A.; et al. Arginase-1: A new immunohistochemical marker of hepatocytes and hepatocellular neoplasms. Am. J. Surg. Pathol. 2010, 34, 1147-1154. [CrossRef]

27. Giedl, J.; Buttner-Herold, M.; Wach, S.; Wullich, B.; Hartmann, A.; Agaimy, A. Hepatocyte differentiation markers in adenocarcinoma of the prostate: Hepatocyte paraffin 1 but not arginase-1 is specifically expressed in a subset of prostatic adenocarcinoma. Hum. Pathol. 2016, 55, 101-107. [CrossRef] [PubMed]

28. Lagana, S.; Hsiao, S.; Bao, F.; Sepulveda, A.; Moreira, R.; Lefkowitch, J.; Remotti, H. HepPar-1 and Arginase-1 Immunohistochemistry in Adenocarcinoma of the Small Intestine and Ampullary Region. Arch. Pathol. Lab. Med. 2015, 139, 791-795. [CrossRef] 
29. Ming, Z.; Zou, Z.; Cai, K.; Xu, Y.I.; Chen, X.; Yi, W.; Luo, J.; Luo, Z. ARG1 functions as a tumor suppressor in breast cancer. Acta Biochim. Biophys. Sin. 2020, 52, 1257-1264. [CrossRef]

30. Yan, X.; Takahara, M.; Xie, L.; Gondo, C.; Setsu, N.; Oda, Y.; Takeuchi, S.; Tu, Y.; Moroi, Y.; Furue, M. Arginine metabolism in soft tissue sarcoma. J. Dermatol. Sci. 2011, 61, 211-215. [CrossRef]

31. Iida, H.; Hata, M.; Kakuno, A.; Hirano, H.; Yamanegi, K.; Yamada, N.; Ohyama, H.; Terada, N.; Yasui, C.; Yamanaka, N.; et al. Expression of hepatocyte markers in mass-forming peripheral and periductal-infiltrating hilar intrahepatic cholangiocarcinomas. Oncol. Lett. 2011, 2, 1041-1046. [CrossRef] [PubMed]

32. Ma, Z.; Lian, J.; Yang, M.; Wuyang, J.; Zhao, C.; Chen, W.; Liu, C.; Zhao, Q.; Lou, C.; Han, J.; et al. Overexpression of Arginase-1 is an indicator of poor prognosis in patients with colorectal cancer. Pathol. Res. Pract. 2019, 215, 152383. [CrossRef]

33. Ren, F.; Weng, W.; Zhang, Q.; Tan, C.; Xu, M.; Zhang, M.; Wang, L.; Sheng, W.; Ni, S.; Huang, D. Clinicopathological features and prognosis of AFP-producing colorectal cancer: A single-center analysis of 20 cases. Cancer Manag. Res. 2019, 11, 4557-4567. [CrossRef] [PubMed]

34. Dancau, A.M.; Simon, R.; Mirlacher, M.; Sauter, G. Tissue microarrays. Methods Mol. Biol 2016, 1381, 53-65. [CrossRef]

35. Mirlacher, M.; Simon, R. Recipient block tma technique. Methods Mol. Biol. 2010, 664, 37-44. [CrossRef] [PubMed]

36. Kononen, J.; Bubendorf, L.; Kallioniemi, A.; Barlund, M.; Schraml, P.; Leighton, S.; Torhorst, J.; Mihatsch, M.J.; Sauter, G.; Kallioniemi, O.P. Tissue microarrays for high-throughput molecular profiling of tumor specimens. Nat. Med. 1998, 4, 844-847. [CrossRef] [PubMed]

37. Uhlen, M.; Bandrowski, A.; Carr, S.; Edwards, A.; Ellenberg, J.; Lundberg, E.; Rimm, D.L.; Rodriguez, H.; Hiltke, T.; Snyder, M.; et al. A proposal for validation of antibodies. Nat. Methods 2016, 13, 823-827. [CrossRef] [PubMed]

38. Uhlen, M.; Fagerberg, L.; Hallstrom, B.M.; Lindskog, C.; Oksvold, P.; Mardinoglu, A.; Sivertsson, A.; Kampf, C.; Sjostedt, E.; Asplund, A.; et al. Tissue-based map of the human proteome. Science 2015, 347, 1260419. [CrossRef]

39. Lizio, M.; Abugessaisa, I.; Noguchi, S.; Kondo, A.; Hasegawa, A.; Hon, C.C.; de Hoon, M.; Severin, J.; Oki, S.; Hayashizaki, Y.; et al. Update of the fantom web resource: Expansion to provide additional transcriptome atlases. Nucleic Acids Res. 2019, 47, D752-D758. [CrossRef]

40. Lizio, M.; Harshbarger, J.; Shimoji, H.; Severin, J.; Kasukawa, T.; Sahin, S.; Abugessaisa, I.; Fukuda, S.; Hori, F.; Ishikawa-Kato, S.; et al. Gateways to the fantom5 promoter level mammalian expression atlas. Genome Biol. 2015, 16, 22. [CrossRef]

41. Consortium, G.T. The genotype-tissue expression (gtex) project. Nat. Genet 2013, 45, 580-585. [CrossRef]

42. Steurer, S.; Schneider, J.; Buscheck, F.; Luebke, A.M.; Kluth, M.; Hube-Magg, C.; Hinsch, A.; Hoflmayer, D.; Weidemann, S.; Fraune, C.; et al. Immunohistochemically detectable thyroglobulin expression in extrathyroidal cancer is $100 \%$ specific for thyroidal tumor origin. Ann. Diagn Pathol. 2021, 54, 151793. [CrossRef]

43. Castel, P.; Rauen, K.A.; McCormick, F. The duality of human oncoproteins: Drivers of cancer and congenital disorders. Nat. Rev. Cancer 2020, 20, 383-397. [CrossRef]

44. Pon, J.R.; Marra, M.A. Driver and passenger mutations in cancer. Annu. Rev. Pathol. 2015, 10, 25-50. [CrossRef] 